\title{
Therapeutic Hypothermia for Cardiac Arrest
}

\author{
Farid Sadaka
}

Additional information is available at the end of the chapter

http://dx.doi.org/10.5772/49374

\section{Introduction}

In the era before Therapeutic Hypothermia ( $\mathrm{TH})$ was recommended and used as a therapeutic modality for out-of-hospital cardiac arrest (OHCA) patients, reported data suggests in-hospital mortality exceeded $58 \% \%^{[1,2,3,4,5,6]}$ Mortality after a sudden and unexpected cardiac arrest (CA) is high, and the chance of survival to hospital discharge has, until recently, remained unchanged.[7] In one report, OHCA in the U.S. has a mortality rate greater than $90 \%$ which results in more than 300,000 deaths per year. ${ }^{[8]}$ Those who survive the devastating event, often retain a hypoxic brain injury and a permanently incapacitating neurologic deficit. ${ }^{[9]}$ Studies of patients who survived to ICU admission but subsequently died in the hospital, brain injury was the cause of death in $68 \%$ after out-of-hospital cardiac arrest and in $23 \%$ after in-hospital cardiac arrest. ${ }^{[10,11]}$ Therapeutic hypothermia, or targeted temperature management, is a therapeutic intervention that is intended to limit neurologic injury after a patient's resuscitation from cardiac arrest.

\section{Mechanisms of neuroprotection}

A cascade of destructive events and processes begins at the cellular level in the minutes to hours following an initial injury. These processes, the result of ischemia and reperfusion, may continue for hours to many days after the initial injury. ${ }^{[12]}$ It is crucial to note that all of these processes after ischemic-reperfusion injury in the brain are temperature dependent; they are all stimulated by fever, and can all be mitigated or blocked by hypothermia. Since most of these processes start within minutes to hours after the injury, then application of hypothermia earlier might be even more beneficial than conventional later application.

\subsection{Slowing of brain metabolism}

When hypothermia was first used in a clinical setting it was presumed that its protective effects were due purely to a slowing of cerebral metabolism, leading to reduced glucose and 
oxygen consumption. Cerebral metabolism decreases by $6 \%$ to $10 \%$ for each $1{ }^{\circ} \mathrm{C}$ reduction in body temperature during cooling. ${ }^{[13,14]}$ This could play a therapeutic effect, but only partially. This mechanism is not the only explanation for the dramatic difference seen despite the positive role of metabolic slowing in neuroprotection.

\subsection{Inhibition of apoptosis}

Therapeutic hypothermia can also effectively inhibit apoptosis [15-17 ]Hypothermia inhibits the early stages of the programmed cell death process. ${ }^{[16]}$ Thus, inhibiting apoptosis is another mechanism by which therapeutic hypothermia could influence the ischemia reperfusion injury or secondary injury early on in the disease process.

\subsection{Inhibition of excitotoxicity}

Excitatory processes play a major role in the pathophysiology of secondary injury postcardiac arrest. ${ }^{[13]}$ Evidence suggests that hypothermia inhibits these harmful excitatory processes occurring in brain cells during ischemia-reperfusion. Ischemic insult to the brain leads to decrease in Adenosine triphosphate (ATP) supplies. ${ }^{[13]}$ This culminates into an influx of calcium (Ca) into the cell through prolonged glutamate exposure inducing a permanent state of hyperexcitability in the neurons (excitotoxicity). All these processes are inhibited by hypothermia very early after injury. Some animal experiments suggest that neuroexcitotoxicity can be blocked or reversed only if the treatment is initiated in the very early stages of the neuroexcitatory cascade. ${ }^{[18-24]}$

\subsection{Antiinflammatory role and decrease in free radical formation}

Acute inflammation early after return of spontaneous circulation (ROSC) plays a harmful role in postcardiac arrest, including cytokines, macrophages, neutrophils, and complement activation, leading to free radical formation. Multiple animal experiments and few clinical studies have shown that hypothermia suppresses all these ischemia-induced inflammatory reactions, leading to a significant reduction in free radical formation. ${ }^{25-28]}$

\subsection{Protection of blood-brain barrier}

Ischemia-reperfusion can also lead to significant disruptions in the blood- brain barrier, which can facilitate the subsequent development of brain edema. Mild hypothermia significantly reduces blood- brain barrier disruptions, and also decreases vascular permeability following ischemia-reperfusion, further decreasing edema formation. ${ }^{[29-31]}$

\subsection{Antithrombotic role}

The coagulation cascade is also activated with ischemia-reperfusion injury leading to intravascular clot formation resulting in microvascular thrombosis in the brain.[32,33] Therapeutic Hypothermia could be beneficial in this instance since platelets number and 
function are decreased with temperatures $<35^{\circ} \mathrm{C}$, and some inhibition of the coagulation cascade develops at temperatures $<33^{\circ} \mathrm{C} .{ }^{[34,35]}$ Vasoconstriction, mediated mainly by thromboxane and endothelin plays a pivotal role in the secondary injury as well. This could also be mitigated by hypothermia ${ }^{[36-38]}$

\section{Clinical evidence}

\subsection{Out of hospital and ventricular fibrillation cardiac arrest}

The first major clinical trials that provided direct evidence of a benefit of therapeutic hypothermia were published in 2002. These studies have indicated that $\mathrm{TH}$ with a reduction of body core temperature (T) to $33{ }^{\circ} \mathrm{C}$ over 12 to 24 hours has improved survival and neurologic outcome in OHCA patients. The European Hypothermia after Cardiac Arrest Study Group demonstrated an improvement in survival from witnessed V-fib cardiac arrest from $41 \%$ to $55 \%$ and an improvement in favorable neurologic outcome among survivors from $39 \%$ to $55 \%$ when $\mathrm{TH}$ of $32-34^{\circ} \mathrm{C}$ was maintained for the first 24 hours post cardiac arrest.39 Bernard demonstrated similar neurologic outcome benefits from 12 hours of $\mathrm{TH}$ at $32-34^{\circ} \mathrm{C}$ induced on the same patient population in Australia.40 Recently, a meta-analysis showed that therapeutic hypothermia is associated with a risk ratio of 1.68 (95\% CI,1.292.07) favoring a good neurologic outcome when compared with normothermia. The metaanalysis concluded the number needed to treat (NNT) to produce one favorable neurological recovery was 6.41 This would translate to improved neurological recovery in > 10,000 patients per year in the U.S.41 Findings were also reviewed from recent literature on the postresuscitation care of cardiac arrest patients using therapeutic hypothermia as part of nontrial treatment. Although varied in their protocols and outcome reporting, results from published investigations confirmed the findings from the landmark randomized controlled trials, in that the use of therapeutic hypothermia increased survival and favorable neurologic outcome. ${ }^{[42]}$

\subsection{In hospital and non-ventricular fibrillation cardiac arrest}

Although ROSC rates are higher in patients with VF and these represent the majority of patients transported to the hospital, many patients still present to the hospital comatose after resuscitation from non-VF arrest. Patients with an initial cardiac rhythm of asystole have a lower rate of survival than patients with VF, because total absence of rhythm is associated with worse underlying causes. Some evidence has now shown that the treatment may be beneficial in cases with non-VF initial rhythm. ${ }^{[43-47]}$ However, other studies involving this patient population did not show outcome benefit. In a recent study of $\mathrm{TH}$ after inhospital cardiac arrest (IHCA), 91\%of patients had an arrest rhythm of asystole or pulseless electrical activity. No difference in neurological outcome at discharge was detected in these non-shockable IHCA patients treated with $\mathrm{TH} .{ }^{48}$ Given this increased severity of neurological injury in non-VF arrest patients, the possible role of $\mathrm{TH}$ remains uncertain. Given such low rates of recovery after non-VF arrest with the use of $\mathrm{TH}$, a prospective study 
comparing TH with normothermia in patients with an initial cardiac rhythm asystole or PEA would require very large numbers of patients to get enough power to show improved outcomes, and thus is unlikely that such trials will be conducted.

\subsection{Asphyxial causes of cardiac arrest}

Suffocation is the second leading cause of death from suicide in the United States, accounting for $22.5 \%$ of the 33300 suicide-related deaths. ${ }^{[49]}$ Victims of near-hanging may carry a poor prognosis even if cardiac arrest has not occurred. Those who suffer cardiac arrest, present with a Glasgow Coma Scale (GCS) of 5 or less, and experience a longer hanging time have the worst prognosis. ${ }^{[0,51]}$ Nearhanging is defined as an unsuccessful attempt at hanging. Victims of near-hanging suffer from strangulation with cerebral ischemia-reperfusion injury rather than a fatal cervical spine injury. Therapeutic Hypothermia has not been prospectively studied in this patient population, and it is doubtful that large randomized, controlled trials comparing TH with normothermia will be conducted. There are few retrospective reviews and case reports and case series on asphyxiated patients with or without cardiac arrests who had good neurologic recovery after therapeutic hypothermia. ${ }^{[52-55]}$ Although it would be difficult to conduct good prospective studies, the compiling case studies, anecdotal evidence, and extrapolated data support the use of therapeutic hypothermia for asphyxial cardiac arrest until more evidence can be obtained.

\section{Guidelines}

In 2005, guidelines for resuscitation and emergency cardiac care of the European Resuscitation Council and the American Heart Association recommended that the core body temperature of unconscious adult patients with spontaneous circulation after a VF OHCA should be lowered to 32 to $34^{\circ} \mathrm{C}$ (Class IIA recommendation). ${ }^{[56]}$ Cooling should be started as soon as possible after the arrest and should be continued for at least 12 to 24 hours.

The guidelines note that patients who have had a cardiac arrest due to nonshockable rhythms and patients who have had a cardiac arrest in the hospital may also benefit from induced hypothermia (Class IIB recommendation). ${ }^{56}$

With more evidence and trials showing the feasibility and the evidence supporting $\mathrm{TH}$ for cardiac arrest patients, the new guidelines by European Resuscitation Council and the American Heart Association in 2010 recommend that comatose (ie, lack of meaningful response to verbal commands) adult patients with ROSC after out-of-hospital VF cardiac arrest should be cooled to $32^{\circ} \mathrm{C}$ to $34^{\circ} \mathrm{C}\left(89.6^{\circ} \mathrm{F}\right.$ to $\left.93.2^{\circ} \mathrm{F}\right)$ for 12 to 24 hours (Class I)..$^{[57]}$ Induced hypothermia also may be considered for comatose adult patients with ROSC after in-hospital cardiac arrest of any initial rhythm or after out-of-hospital cardiac arrest with an initial rhythm of pulseless electrical activity or asystole (Class IIb).[57] Active rewarming should be avoided in comatose patients who spontaneously develop a mild degree of 
hypothermia $\left(32^{\circ} \mathrm{C}\left[89.6^{\circ} \mathrm{F}\right]\right)$ after resuscitation from cardiac arrest during the first 48 hours after ROSC. (Class III). ${ }^{[57]}$

\section{Cooling methods}

\subsection{Methods for induction of therapeutic hypothermia}

Bernard et al., reported the results of a clinical trial of the rapid infusion of large-volume (30 $\mathrm{ml} / \mathrm{kg})$, ice-cold $\left(4^{\circ} \mathrm{C}\right)$ lactated ringer's solution in comatose survivors of OHCA. This study found that this approach decreased core temperature by $1.6^{\circ} \mathrm{C}$ over 25 minutes with no adverse events. ${ }^{[58]}$ Polderman, et al., used in addition to surface cooling, 30 $\mathrm{ml} / \mathrm{kg}$ (mean 2.3 liters) of cold normal saline over 50 minutes that showed similar results. ${ }^{[59]}$ Several small randomized trials, and nonrandomized observational and retrospective trials, looked at prehospital cooling initiation for patients with $\mathrm{OHCA}$ with large-volume ice-cold $\left(4^{\circ} \mathrm{C}\right)$ fluids (discussed in more detail in a separate chapter: Prehospital Therapeutic Hypothermia for Cardiac Arrest). ${ }^{[60-68]}$ All these studies documented the safety and feasibility if ice-cold fluids for the rapid induction of therapeutic hypothermia. Other promising methods for induction of hypothermia include transnasal cooling device [69], self-adhesive cooling pads [70], and cranial cooling caps. ${ }^{[71]}$

\subsection{Methods for maintenance of therapeutic hypothermia}

An ideal cooling method would be one that will help with rapid induction of cooling, costeffective, easily implemented, safe, effective, and able to maintain the temperature with minimal variations.

\subsubsection{Surface cooling}

Ice packs are still used in some centers for induction and maintenance of hypothermia, by applying them to the head, neck, torso and extremities. Disadvantages of this method include slow cooling rate, labor-intensive for the nurses, and wide fluctuations with overshooting and undercooling or unintentional rewarming.[40,72,73]

An effective surface cooling system uses cooling blanket (Arctic Sun, Medivance, Louisville, CO, USA). This technology can cool as fast as $1.2^{\circ} \mathrm{C}$ per hour through especially designed pads, is radiolucent (can be used during cardiac catheterization), has minimal temperature variation (operates with feedback control), and can perform active controlled rewarming. The pads can be applied easily by the nurses. Disadvantages include expense, possible skin sloughing, and slower cooling rates in very obese people. ${ }^{[72,74]}$

A promising technology is the Thermosuit System (Life Recovery Systems, Kinnelon, NJ, USA), which surrounds patients directly with cool water and also possesses a feedback control mechanism. Animal studies suggest that it provides a cooling rate of $9.7^{\circ} \mathrm{C}$ per hour in $30-\mathrm{kg}$ pigs, versus $3.0^{\circ} \mathrm{C}$ per hour in humans. Disadvantages include expense and hindering appropriate physical exams. ${ }^{[75,76]}$ 


\subsubsection{Intravascular cooling}

The CoolGard System (Alsius, Irvine, CA, USA) is one of the products that uses Intravascular devices. This technology works by exchanging heat through a catheter containing circulating saline at a controlled temperature with a feedback of patient temperature. This technology can cool as fast as 1 to $1.5^{\circ} \mathrm{C}$ per hour, is very good at maintaining goal temperature (feedback mechanism) and cal also provide active controlled rewarming. Disadvantages are those of central venous catheters (risks of bleeding, vessel thrombosis, and catheter-related infection). It also requires placement by a physician, which if not readily available, may delay initiation of this important and timely therapy. ${ }^{[77.78]}$

Although many devices are available to achieve and maintain therapeutic hypothermia, there are no current data recommending one method over another, or comparing them against each other. Several factors need to be taken into consideration, such as patient factors, nursing factors and nurse to patient ratios, and institutional factors when making a decision regarding the optimal method.

\section{Conclusion}

On the basis of current evidence, comatose (ie, lack of meaningful response to verbal commands) adult patients with ROSC after out-of-hospital VF cardiac arrest should be cooled to $32^{\circ} \mathrm{C}$ to $34^{\circ} \mathrm{C}\left(89.6^{\circ} \mathrm{F}\right.$ to $\left.93.2^{\circ} \mathrm{F}\right)$ for 12 to 24 hours, as fast as possible. Therapeutic Hypothermia should be strongly considered for other rhythms, for inhospital arrests, and for cardiac arrest secondary to asphyxia. Intensivists should be familiar with techniques to induce, maintain, and rewarm from therapeutic hypothermia, and select the most appropriate method for a given patient, and institution. Research questions for the future are whether very early cooling, or longer cooling periods (eg, $72 \mathrm{~h}$ ), or both can further improve outcome.

\section{Author details}

Farid Sadaka

Mercy Hospital St Louis/St Louis University ,Critical Care Medicine/Neurocritical Care, St Louis

\section{Acknowledgement}

No additional acknowledgements.

\section{Conflicts of interest}

The author reports no conflicts of interest.

The author declares that no competing financial interests exist.

The author reports that no potential conflicts of interest exist with any companies/organizations whose products or services may be discussed in this article. 


\section{References}

[1] Stiell IG, Wells GA, Field B, Spaite DW, Nesbitt LP, De Maio VJ, Nichol G, Cousineau D, Blackburn J, Munkley D, Luinstra-Toohey L, Campeau T, Dagnone E, Lyver M; Ontario Prehospital Advanced Life Support Study Group (2004) Advanced cardiac life support in out-of-hospital cardiac arrest. N Engl J Med 351:647- 656.

[2] Keenan SP, Dodek P, Martin C, Priestap F, Norena M, Wong H (2007) Variation in length of intensive care unit stay after cardiac arrest: where you are is as important as who you are. Crit Care Med 35: 836-841.

[3] Mashiko K, Otsuka T, Shimazaki S, Kohama A, Kamishima G, Katsurada K, Sawada Y, Matsubara I, Yamaguchi K (2002) An outcome study of out-of-hospital cardiac arrest using the Utstein template: a Japanese experience. Resuscitation 55:241-246.

[4] Nolan JP, Laver SR, Welch CA, Harrison DA, Gupta V, Rowan K (2007) Outcome following admission to UK intensive care units after cardiac arrest: a secondary analysis of the ICNARC Case Mix Programme Database. Anaesthesia 62:1207-1216.

[5] Langhelle A, Tyvold SS, Lexow K, Hapnes SA, Sunde K, Steen PA (2003) In-hospital factors associated with improved outcome after out-ofhospital cardiac arrest: a comparison between four regions in Norway. Resuscitation 56:247-263.

[6] Herlitz J, Engdahl J, Svensson L, Angquist KA, Silfverstolpe J, Holmberg S (2006) Major differences in 1-month survival between hospitals in Sweden among initial survivors of out-of-hospital cardiac arrest. Resuscitation 70:404-409.

[7] Neumar RW, Nolan JP, Adrie C, Aibiki M, Berg RA, Böttiger BW, Callaway C, Clark RSB, Geocadin RG, Jauch EC, Kern KB, Laurent I, Longstreth WT Jr, Merchant RM, Morley P, Morrison LJ, Nadkarni V, Peberdy MA, Rivers EP, Rodriguez-Nunez A, Sellke FW, Spaulding C, Sunde K, Vanden Hoek T (2008) Post- cardiac arrest syndrome: epidemiology, pathophysiology, treatment, and prognostication: a consensus statement from the International Liaison Committee on Resuscitation (American Heart Association, Australian and New Zealand Council on Resuscitation, European Resuscitation Council, Heart and Stroke Foundation of Canada, InterAmerican Heart Foundation, Resuscitation Council of Asia, and the Resuscitation Council of Southern Africa); the American Heart Association Emergency Cardiovascular Care Committee; the Council on Cardiovascular Surgery and Anesthesia; the Council on Cardiopulmonary, Perioperative, and Critical Care; the Council on Clinical Cardiology; and the Stroke Council. Circulation 118:2452-2483.

[8] Eisenberg MS, Mengert TJ (2001) Cardiac Resuscitation. N Engl J Med 334: 1304-1313.

[9] Bunch TJ, White RD, Smith GE, Hodge DO, Gersh BJ, Hammill SC, Shen WK, Packer DL (1998) Long-term subjective memory function in ventricular fibrillation out-ofhospital cardiac arrest survivors resuscitated by early defibrillation. Resuscitation 36:111-122.

[10] Laver S, Farrow C, Turner D, Nolan J (2004) Mode of death after admission to an intensive care unit following cardiac arrest. Intensive Care Med 30:2126 -2128.

[11] Jacobs I, Nadkarni V, Bahr J, Berg RA, Billi JE, Bossaert L, Cassan P, Coovadia A, D'Este K, Finn J, Halperin H, Handley A, Herlitz J, Hickey R, Idris A, Kloeck W, Larkin GL, 
Mancini ME, Mason P, Mears G, Monsieurs K, Montgomery W, Morley P, Nichol G, Nolan J, Okada K, Perlman J, Shuster M, Steen PA, Sterz F, Tibballs J, Timerman S, Truitt T, Zideman D; International Liaison Committee on Resuscitation (2004) Cardiac arrest and cardiopulmonary resuscitation outcome reports: update and simplification of the Utstein templates for resuscitation registries: a statement for healthcare professionals from a task force of the International Liaison Committee on Resuscitation (American Heart Association, European Resuscitation Council, Australian Resuscitation Council, New Zealand Resuscitation Council, Heart and Stroke Foundation of Canada, InterAmerican Heart Foundation, Resuscitation Council of Southern Africa). Resuscitation 63:233-249.

[12] Polderman KH (2008) Induced hypothermia and fever control for prevention and treatment of neurological injuries. Lancet 371: 1955-1969.

[13] Small DL, Morley P, Buchan AM (1999) Biology of ischemic cerebral cell death. Prog Cardiovasc Dis 42:185-207.

[14] Hagerdal M, Harp J, Nilsson L, Siesjö BK (1975) The effect of induced hypothermia upon oxygen consumption in the rat brain. J Neurochem 24:311-316.

[15] Povlishock JT, Buki A, Koiziumi H, Stone J, Okonkwo DO (1999) Initiating mechanisms involved in the pathobiology of traumatically induced axonal injury and interventions targeted at blunting their progression. Acta Neurochir Suppl (Wien) 73:15-20

[16] Xu L, Yenari MA, Steinberg GK, Giffard RG (2002) Mild hypothermia reduces apoptosis of mouse neurons in vitro early in the cascade. J Cereb Blood Flow Metab 22:21-28

[17] Ning XH, Chen SH, Xu CS, Li L, Yao LY, Qian K, Krueger JJ, Hyyti OM, Portman MA (2002) Hypothermic protection of the ischemic heart via alterations in apoptotic pathways as assessed by gene array analysis. J Appl Physiol 92:2200-2207

[18] Siesjo BK, Bengtsson F, Grampp W, Theander S (1989) Calcium, excitotoxins, and neuronal death in brain. Ann NY Acad Sci 568: 234-251.

[19] Leker RR, Shohami E (2002) Cerebral ischemia and trauma-different etiologies yet similar mechanisms: Neuroprotective opportunities. Brain Res Brain Res Rev 39: 55-73

[20] Dempsey RJ, Combs DJ, Maley ME, Cowen DE, Roy MW, Donaldson DL (1987) Moderate hypothermia reduces postischemic edema development and leukotriene production. Neurosurgery 21:177-181.

[21] Globus MY-T, Alonso O, Dietrich WD, Busto R, Ginsberg MD (1995) Glutamate release and free radical production following brain injury: Effects of posttraumatic hypothermia. J Neurochem 65:1704-1711.

[22] Busto R, Globus MY, Dietrich WD, Martinez E, Valdés I, Ginsberg MD (1989) Effect of mild hypothermia on ischemia-induced release of neurotransmitters and free fatty acids in rat brain. Stroke 20:904-910.

[23] Takata K, Takeda Y, Morita K (2005) Effects of hypothermia for a short period on histological outcome and extracellular glutamate concentration during and after cardiac arrest in rats. Crit Care Med 33: 1340-1345.

[24] Kuboyama K, Safar P, Radovsky A, Tisherman SA, Stezoski SW, Alexander H (1993) Delay in cooling negates the beneficial effect of mild resuscitative cerebral hypothermia 
after cardiac arrest in dogs: A prospective, randomized study. Crit Care Med 21:13481358.

[25] Aibiki M, Maekawa S, Ogura S, Kinoshita Y, Kawai N, Yokono S (1999) Effect of moderate hypothermia on systemic and internal jugular plasma IL-6 levels after traumatic brain injury in humans. J Neurotrauma 16:225-232.

[26] Schmidt OI, Heyde CE, Ertel W, Stahel PF (2005) Closed head injury-an inflammatory disease? Brain Res Brain Res Rev 48: 388-399.

[27] Kimura A, Sakurada S, Ohkuni H, Todome Y, Kurata K (2002) Moderate hypothermia delays proinflammatory cytokine production of human peripheral blood mononuclear cells. Crit Care Med 30:1499-1502.

[28] Dietrich WD, Chatzipanteli K, Vitarbo E, Wada K, Kinoshita K (2004) The role of inflammatory processes in the pathophysiology and treatment of brain and spinal cord trauma. Acta Neurochir Suppl 89:69-74.

[29] Chi OZ, Liu X, Weiss HR (2001) Effects of mild hypothermia on blood- brain barrier disruption during isoflurane or pentobarbital anesthesia. Anesthesiology 95:933-938.

[30] Smith SL, Hall ED (1996) Mild pre- and posttraumatic hypothermia attenuates bloodbrain barrier damage following controlled cortical impact injury in the rat. J Neurotrauma 13:1-9.

[31] Jurkovich GJ, Pitt RM, Curreri PW, Granger DN (1988) Hypothermia prevents increased capillary permeability following ischemia-reperfusion injury. J Surg Res 44:514-521.

[32] Bo"ttiger BW, Motsch J, Bohrer H, Böker T, Aulmann M, Nawroth PP, Martin E (1995) Activation of blood coagulation after cardiac arrest is not balanced adequately by activation of endogenous fibrinolysis. Circulation 92:2572-2578.

[33] Gando S, Kameue T, Nanzaki S, Nakanishi Y (1997) Massive fibrin formation with consecutive impairment of fibrinolysis in patients with out-of-hospital cardiac arrest. Thromb Haemost 77:278-282.

[34] Michelson AD, MacGregor H, Barnard MR, Kestin AS, Rohrer MJ, Valeri CR (1994) Hypothermia-induced reversible platelet dysfunction. Thromb Haemost 71:633-640.

[35] Valeri CR, MacGregor H, Cassidy G, Tinney R, Pompei F (1995) Effects of temperature on bleeding time and clotting time in normal male and female volunteers. Crit Care Med 23: 698-704.

[36] Chen ST, Hsu CY, Hogan EL, Halushka PV, Linet OI, Yatsu FM (1986) Thromboxane, prostacyclin, and leukotrienes in cerebral ischemia. Neurology 36: 466-470.

[37] Maekawa S, Aibiki M, Ogura S (1997) Mild hypothermia suppresses thromboxane B2 production in brain-injured patients. In: The Immune Consequences of Trauma, Shock and Sepsis. Mechanisms and Therapeutic Approaches. Faist E (Ed). Bologna, Italy, Monduzzi Editore pp 135-138.

[38] Aibiki M, Maekawa S, Yokono S (2000) Moderate hypothermia improves imbalances of thromboxane A2 and prostaglandin I2 production after traumatic brain injury in humans. Crit Care Med 28:3902-3906.

[39] Hypothermia After Cardiac Arrest Study Group (2002) Mild therapeutic hypothermia to improve the neurologic outcome after cardiac arrest. N Engl J Med 346:549 -556. 
[40] Bernard SA, Gray TW, Buist MD, Jones BM, Silvester W, Gutteridge G, Smith K (2002) Treatment of comatose survivors of out-of-hospital cardiac arrest with induced hypothermia. N Engl J Med 346:557-563.

[41] Holzer M, Bernard SA, Hachimi-Idrissi S, Roine RO, Sterz F, Müllner M; Collaborative Group on Induced Hypothermia for Neuroprotection After Cardiac Arrest (2005) Hypothermia for neuroprotection after cardiac arrest: systematic review and individual patient data meta-analysis. Crit Care Med 33:414-418.

[42] Sagalyn E, Band RA, Gaieski DF Abella BS (2009) Therapeutic hypothermia after cardiac arrest in clinical practice: review and compilation of recent experiences. Crit Care Med 37(7 Suppl):S223-6.

[43] Oddo M, Schaller MD, Feihl F, Ribordy V, Liaudet L (2006) From evidence to clinical practice: effective implementation of therapeutic hypothermia to improve patient outcome after cardiac arrest. Crit Care Med 34: 1865-1873.

[44] Sunde K, Pytte M, Jacobsen D, Mangschau A, Jensen LP, Smedsrud C, Draegni T, Steen PA (2007) Implementation of a standardised treatment protocol for post resuscitation care after out-of-hospital cardiac arrest. Resuscitation 73:29 -39.

[45] Busch M, Soreide E, Lossius HM, Lexow K, Dickstein K (2006) Rapid implementation of therapeutic hypothermia in comatose out-of-hospital cardiac arrest survivors. Acta Anaesthesiol Scand 50:1277-1283.

[46] Arrich J; European Resuscitation Council Hypothermia After Cardiac Arrest Registry Study Group (2007) Clinical application of mild therapeutic hypothermia after cardiac arrest. Crit Care Med 35:1041-1047.

[47] Holzer M, Müllner M, Sterz F, Robak O, Kliegel A, Losert H, Sodeck G, Uray T, Zeiner A, Laggner AN (2006) Efficacy and safety of endovascular cooling after cardiac arrest: cohort study and Bayesian approach. Stroke 37:1792-1797.

[48] Kory P, Fukunaga M, Mathew JP, Singh B, Szainwald L, Mosak J, Marks M, Berg D, Saadia M, Katz A, Mayo PH (2012) Outcomes of Mild Therapeutic Hypothermia After In-Hospital Cardiac Arrest. Neurocrit Care [Epub ahead of print].

[49] Statistical abstract of the U.S. In: Bureau USC, ed 2005-2006.

[50] Matsuyama T, Okuchi K, Tadahiko S, Murao Y (2004) Prognostic factors in hanging injuries. Am J Emerg Med 22(3):207-10.

[51] Penney DJ, Stewart P (2002) Prognostic outcome indicators following hanging injuries. Resuscitation 54:27-9.

[52] Borgquist O, Friberg H (2009) Therapeutic hypothermia for comatose survivors after near-hanging - a retrospective analysis. Resuscitation 80:210-2.

[53] Jehle D, Meyer M, Gemme S (2010) Beneficial response to mild therapeutic hypothermia for comatose survivors of near-hanging. Am J Emerg Med 28:390.e1-e3.

[54] Howell MA, Guly HR (1996) Near hanging presenting to an accident and emergency department. Am J Accid Emerg Med 13:135-6.

[55] Sadaka F, Wood MP, Cox M (2012) Therapeutic hypothermia for a comatose survivor of near-hanging. Am J Emerg Med 30(1):251.e1-2. 
[56] 2005 American Heart Association Guidelines for Cardiopulmonary Resuscitation and Emergency Cardiovascular Care Part 7.5: Postresuscitation Support. Circulation 112:IV84-IV- 88.

[57] Peberdy MA, Callaway CW, Neumar RW, Geocadin RG, Zimmerman JL, Donnino M, Gabrielli A, Silvers SM, Zaritsky AL, Merchant R, Vanden Hoek TL, Kronick SL (2010) Part 9: post- cardiac arrest care: 2010 American Heart Association Guidelines for Cardiopulmonary Resuscitation and Emergency Cardiovascular Care. Circulation 122(suppl 3):S768 -S786.

[58] Bernard S, Buist M, Monteiro O, Smith K (2003) Induced hypothermia using large volume, ice-cold intravenous fluid in comatose survivors of out-of- hospital cardiac arrest: a preliminary report. Resuscitation 56:9-13.

[59] Polderman KH, Rijnsburger ER, Peerdeman SM, Girbes AR (2005) Induction of hypothermia in patients with various types of neurologic injury with use of large volumes of ice-cold intravenous fluid. Crit Care Med 33:2744 -2751.

[60] Kim F, Olsufka M, Longstreth WT Jr, Maynard C, Carlbom D, Deem S, Kudenchuk P, Copass MK, Cobb LA (2007) Pilot randomized clinical trial of prehospital induction of mild hypothermia in out ofhospital cardiac arrest patients with a rapid infusion of 4 degrees C normal saline. Circulation 115:3064-70.

[61] Kämäräinen A, Virkkunen I, Tenhunen J, Yli-Hankala A, Silfvast T (2009) Prehospital therapeutic hypothermia for comatose survivors of cardiac arrest: a randomized controlled trial. Acta Anaesthesiol Scand 53:900-7.

[62] Bernard SA, Smith K, Cameron P, Masci K, Taylor DM, Cooper DJ, Kelly AM, Silvester W; Rapid Infusion of Cold Hartmanns (RICH) Investigators (2010) Induction of therapeutic hypothermia by paramedics after resuscitation from out-of-hospital ventricular fibrillation cardiac arrest: a randomized controlled trial. Circulation 122(7):737-42.

[63] Bernard SA, Smith K, Cameron P, Masci K, Taylor DM, Cooper DJ, Kelly AM, Silvester W; Rapid Infusion of Cold Hartmanns (RICH) Investigators (2012) Induction of prehospital therapeutic hypothermia after resuscitation from nonventricular fibrillation cardiac arrest. Crit Care Med 40(3):747-53.

[64] Virkkunen I, Yli-Hankala A, Silfvast T (2004) Induction of therapeutic hypothermia after cardiac arrest in prehospital patients using ice-cold Ringer's solution: a pilot study. Resuscitation. 62:299-302.

[65] Hammer L, Vitrat F, Savary D, Debaty G, Santre C, Durand M, Dessertaine G, Timsit JF (2009) Immediate prehospital hypothermia protocol in comatose survivors of out-ofhospital cardiac arrest. Am J Emerg Med. 27:570-3.

[66] Kämäräinen A, Virkkunen I, Tenhunen J, Yli-Hankala A, Silfvast T (2008) Induction of therapeutic hypothermia during prehospital CPR using ice-cold intravenous fluid. Resuscitation 79:205-11.

[67] Bruel C, Parienti JJ, Marie W, Arrot X, Daubin C, Du Cheyron D, Massetti M, Charbonneau P (2008) Mild hypothermia during advanced life support: a preliminary study in out-of-hospital cardiac arrest. Crit Care 12:R31. 
[68] Garrett JS, Studnek JR, Blackwell T, Vandeventer S, Pearson DA, Heffner AC, Reades R (2011) The association between intra-arrest therapeutic hypothermia and return of spontaneous circulation among individuals experiencing out of hospital cardiac arrest. Resuscitation 82(1):21-5.

[69] Castre'n M, Nordberg P, Svensson L, Taccone F, Vincent JL, Desruelles D, Eichwede F, Mols P, Schwab T, Vergnion M, Storm C, Pesenti A, Pachl J, Gue'risse F, Elste T, Roessler M, Fritz H, Durnez P, Busch H-J, Inderbitzen B, Barbut D (2010) Intra-arrest transnasal evaporative cooling: a randomized, prehospital, multicenter study (PRINCE: Pre-ROSC Intra-Nasal Cooling Effectiveness). Circulation 122:729-736.

[70] Uray T, Malzer R, on behalf of the Vienna Hypothermia After Cardiac Arrest (HACA) Study Group (2008) Out-of-hospital surface cooling to induce mild hypothermia in human cardiac arrest: A feasibility trial. Resuscitation 77:331-338.

[71] Storm C, Schefold JC, Kerner T, Schmidbauer W, Gloza J, Krueger A, Jörres A, Hasper D (2008) Prehospital cooling with hypothermia caps (PreCoCa): a feasibility study. Clin Res Cardiol 97:768-72.

[72] Janata A, Holzer M (2009) Hypothermia after cardiac arrest. Prog Cardiovasc Dis 52(2):168-79.

[73] Merchant RM, Abella BS, Peberdy MA, Soar J, Ong ME, Schmidt GA, Becker LB, Vanden Hoek TL (2006) Therapeutic hypothermia after cardiac arrest: unintentional overcooling is common using ice packs and conventional cooling blankets. Crit Care Med 34:S490-S494.

[74] Haugk M, Sterz F, Grassberger M, Uray T, Kliegel A, Janata A, Richling N, Herkner H, Laggner AN (2007) Feasibility and efficacy of a new non-invasive surface cooling device in post-resuscitation intensive care medicine. Resuscitation 75(1):76-81.

[75] Schratter A, Weihs W, Holzer M, Janata A, Behringer W, Losert UM, Ohley WJ, Schock RB, Sterz F (2007) External cardiac defibrillation during wet surface cooling in pigs. Am J Emerg Med 25(4):420-4.

[76] Howes D, Ohley W, Dorian P, Klock C, Freedman R, Schock R, Krizanac D, Holzer M (2010) Rapid induction of therapeutic hypothermia using convective-immersion surface cooling: safety, efficacy and outcomes. Resuscitation 81(4):388 -92.

[77] Holzer M, Mullner M, Sterz F, Robak O, Kliegel A, Losert H, Sodeck G, Uray T, Zeiner A, Laggner AN (2006) Efficacy and safety of endovascular cooling after cardiac arrest: cohort study and Bayesian approach. Stroke 37(7):1792-7.

[78] Al-Senani FM, Graffagnino C, Grotta JC, Saiki R, Wood D, Chung W, Palmer G, Collins KA (2004) A prospective, multicenter pilot study to evaluate the feasibility and safety of using the CoolGard System and Icy catheter following cardiac arrest. Resuscitation 62(2):143-50. 